\title{
How to grow trees on the wastes of a boreal gold mine - identification of the main physico-chemical limitations
}

M. Larchevêque Université du Québec en Abitibi-Témiscamingue; and Osisko Mining Corporation, Canada

A. Desrochers Université du Québec en Abitibi-Témiscamingue, Canada

B. Bussière Université du Québec en Abitibi-Témiscamingue, Canada

H. Cartier Osisko Mining Corporation, Canada

C. Baribeau Osisko Mining Corporation, Canada

C. Pednault Osisko Mining Corporation, Canada

J-S. David Ressources d'Arianne, Canada

\begin{abstract}
The Osisko gold mine in Malartic, Quebec (Canada) is an open-pit mine producing low grade ore and is designed to operate at 55,000 metric ton per day. Its non-acid generating wastes will eventually cover large surfaces that will need to be reclaimed. To minimise mine impacts on water consumption, milling wastes will be deposited in the form of thickened tailings (68\% DM). To our knowledge, no study of vegetation establishment on this type of mine waste has yet been published.
\end{abstract}

The Osisko mine is located on the edge of a small town. Consequently, visual aspects of mine waste reclamation are a major concern with respect to social acceptability of the company. Since the surrounding region is covered by boreal forest, tree colonisation appears essential. Tree plantations may accelerate the conversion of degraded lands into forests and also add biodiversity to the area.

Two studies were conducted, one on overburden waste rock and a second on milled tailings. In the first study, plantations were established on compacted waste rock (10:1 slope) covered with overburden topsoil or subsoil at two compaction intensities. The second study was conducted in a glasshouse to evaluate the thickened tailings' capacity to sustain tree growth (tamarack, jack pine, black spruce, basket willow, hybrid poplars, and green alder). Tailings alone or mixed with several amendments were tested (overburden soils, vermicomposts from food wastes, chicken manure, peat). In addition, we compared the use of a thin or a thick layer of overburden topsoil.

We showed that direct planting in the thickened tailings was not suitable for boreal trees under glasshouse conditions. This substrate high water retention capacity and low macroporosity (or air-filled porosity, $\leq 8 \%$ ) may be responsible for tree death by limiting $\mathrm{O}_{2}$ availability required for root respiration. To overcome this aeration stress, an organic matter-rich amendment should be used to raise macroporosity to levels suitable for tree growth. Peat (8\% DM in the mixture) was the most effective amendment for improving macroporosity (27\%) compared to other amendments, including two different composts (22 and 35\% DM in the mixtures leading to 14 and 17\% macroporosity, respectively) and mine soils. The use of composts produced appropriate macroporosity levels but also increased electrical conductivity to levels $(3.4$ to $4.1 \mathrm{mS}$ $\mathrm{cm}^{-1}$ ) limiting broad-leaved species survival and conifer biomass production. No trace metal contamination of the trees occurred in the mixtures, probably due to the near-neutral $\mathrm{pH}$ conferred by the tailings. Moreover, the presence of underlying alkaline tailings limited $\mathrm{Mn}, \mathrm{Zn}$, and Al phytotoxicity of the acidic overburden topsoil layer from occurring in tree leaves. Consequently, growth of jack pine and all broadleaved species was improved with a thin layer compared to a thick layer of overburden soil, although these trees also showed Cu accumulation in their fine roots $\left(>100 \mathrm{mg} \cdot \mathrm{kg}^{-1}\right)$. 
This study demonstrated that the use of thin layers of acidic overburden topsoil above alkaline thickened tailings could improve tree growth and accelerate landscape reclamation.

\section{Introduction}

Woody vegetation is rarely used to reclaim metalliferous mine wastes in Canada despite the occurring of mines in forested landscapes. Yet trees present clear advantages for mine reclamation by rapidly attaining an aesthetic effect ('greening up'), restoring biodiversity, and increasing $\mathrm{CO}_{2}$ fixation to compensate for emissions that were generated during the mining and extraction process. Trees accelerate the conversion of degraded lands into forests (Parrotta et al., 1997) because they facilitate native plant species recolonisation at canopy closure (Strong, 2000). In contrast, the highly competitive herbaceous species that are routinely used for reclamation of mined sites may prevent establishment of native tree species (Drake, 1986; Halofsky and McCormick, 2005; Kost and Vimmerstedt, 1994; Skousen et al., 2006; Washburn et al., 1994) and arrest natural succession at an herbaceous stage in these particular ecosystems.

However, trees are especially sensitive to soil porosity, pH, and salt levels (Angel et al., 2006; Emerson et al., 2009) and their use for reclamation of mine wastes raises several challenges. First, metalliferous mine wastes are generally not favourable to vegetation establishment because they lack organic matter, nutrients, and soil organisms (Burger and Zipper, 2002). Second, they lack physical structure and contain potentially phytotoxic levels of salts and heavy metals (Tordoff et al., 2000).

Thickened tailings are a new emerging technology for the surface deposition of milling wastes (e.g. Robinsky et al., 1991). They are characterised by a solid content of 50 to $70 \%$ when laid down, which reduces water consumption, especially in open-pit mines that process low grade ores and which extract large rock quantities, or which are located in arid areas. Their basic properties are similar to those of conventionally deposited tailings (slurried), but they routinely have a more homogeneous grain size distribution within tailings impoundments (Bussière, 2007). Their homogeneity induces high water saturation levels in the impoundment, which may cause anoxic conditions for tree roots. In contrast, waste rock piles exhibit very heterogeneous granulometry and retain little water (Anterrieu et al., 2010; Poisson et al., 2009).

Several experiments were conducted to evaluate survival, growth, and nutrient and trace metal concentrations of tree species (tamarack, jack pine, black spruce, basket willow, hybrid poplars, and green alder) planted in mine wastes with enriching agents. Two glasshouse experiments were established on thickened tailings and another on waste rocks in the field. The general objective of these studies was to understand the main physico-chemical limitations for tree development on each substrate and to recommend a strategy for successful reclamation of those wastes with trees.

\section{$2 \quad$ Material and methods}

\subsection{Plant material and growth conditions}

Trees were native species from the surrounding forested region or adapted to boreal conditions and locally produced by the Ministère des Ressources Naturelles et de la Faune du Québec (MRNF) except for alder stock (serres de Guyenne, QC). Two-year-old seedlings were grown in $110 \mathrm{~cm}^{3}$ containers for jack pine (Pinus banksiana Lamb.), black spruce (Picea mariana (Mill.) BSP), tamarack or eastern larch (Larix laricina (Du Roi) K. Koch), and green alder (Alnus crispa (Aiton) Pursh). Hybrid poplar and willow stock consisted of clonally propagated one-year-old whips from Populus maximowiczii Henry $\times$ P. balsamifera $\mathrm{L}$. $(\mathrm{M} \times \mathrm{B}$, 915319), $P . \times$ canadensis Moench $\times$ P. maximowiczii ( $\mathrm{DN} \times \mathrm{M}, 916004)$, and Salix viminalis $\mathrm{L}$. (basket willow).

In the first glasshouse study on tailings, all species were planted on 15 June 2010 in $3.6 \mathrm{~L}$ (container stock) or $7 \mathrm{~L}$ (whips) pots. They were grown over two growing seasons of three months each (separated by four months dormancy, with a natural winter photoperiod and $5^{\circ} \mathrm{C}$ temperature). Substrate moisture was checked daily and trees were regularly watered to field capacity. 
In the second glasshouse study on tailings, $10 \mathrm{~cm}$ cuttings were obtained from DN×M poplar whips and planted in February 2012 for five weeks in $110 \mathrm{~cm}^{3}$ containers. The cuttings were watered to field capacity three times a week. For both experiments, glasshouse conditions were set to an $18 \mathrm{~h}$ photoperiod and a temperature of about $25^{\circ} \mathrm{C}$.

The field experiment was set up on compacted waste rock, in which jack pine, tamarack, $M \times B$ poplar, and basket willow were planted in mid-July 2011 (Osisko Malartic mine, 48 $13^{\prime} \mathrm{N}, 78^{\circ} 12^{\prime} \mathrm{W}$ ). Unrooted whips were planted to a depth of $30 \mathrm{~cm}$ in the substrate. In this boreal region, the growing season typically begins in mid-May and ends in early October. Average annual temperature is $1^{\circ} \mathrm{C}$, and the average number of frost-free days is 80 . Mean annual precipitation is around $900 \mathrm{~mm}$ (Environment Canada, 2004).

\subsection{Substrates}

In the first glasshouse study, six substrates were tested (Table 1):

- Thickened tailings alone (T), fertilised bi-weekly with liquid fertiliser (20-20-20 NPK, $4{\mathrm{~mL} . L^{-1}}$ for broad-leaved species and 30-10-10 NPK, $2.2{\mathrm{~mL} . L^{-1}}$ for conifers, Botanix, Boucherville, QC, Canada).

- Thickened tailings with chicken manure (MT) inserted in slits made with a blade. Chicken manure was locally produced, dried and granulated (Richard farm, Rivière-Héva, QC). Each pot received $184 \mathrm{~g}$ dry weight (DW).

- Thickened tailings mixed with compost (CT) made from vermicomposted food wastes provided by the Eugenia farm (Bic, QC). Two-thirds compost and one-third thickened tailings by volume (23\% of compost, DW).

- Topsoil alone, non-stockpiled (thick layer) (S).

- Topsoil above thickened tailings (thin layer) (ST1). The topsoil layer had a thickness of 12 to $14 \mathrm{~cm}$ with a 6 to $7 \mathrm{~cm}$ layer of thickened tailings at the bottom of the pot.

- Thickened tailings mixed with topsoil (ST2). Two-thirds topsoil and one third thickened tailings by volume (39\% of topsoil, DW).

Thickened tailings came from the Canadian Malartic mine (property of Osisko Mining Corporation) and consisted of finely milled wastes $\left(D_{10}: 0.004 \mathrm{~mm}, D_{60}: 0.031 \mathrm{~mm}, C_{U}: 7.3,86 \%\right.$ particles $<80 \mu \mathrm{m}$ ) from the gold extraction process (cyanide leaching). They were freshly made when used and had not been exposed to outdoor conditions. The tailings had undergone a cyanide destruction process $\left(\mathrm{SO}_{2} / \mathrm{O}_{2}\right.$ technology) that left free $\mathrm{CN}^{-}$concentrations lower than $8 \mathrm{mg} \cdot \mathrm{kg}^{-1}$. Osisko Malartic tailings are low-sulphur (around $1 \% \mathrm{~S}$ ) and contain around $4.3 \%$ calcite, which can neutralise acidity. The topsoil also came from the Canadian Malartic mine site. It consisted of the uppermost $15 \mathrm{~cm} \mathrm{(H,Ah} \mathrm{and/or} \mathrm{Bh} \mathrm{horizons)} \mathrm{of} \mathrm{a} \mathrm{dystric} \mathrm{brunisol}$ (Agriculture and Agri-Food Canada, 2010) scraped from a previously forested site that had contained coniferous and broad-leaved species. The topsoil was sieved to pass a $0.67 \mathrm{~cm}$ mesh screen and used a few days after being collected. The topsoil alone treatment represented the use of a thick topsoil layer that would prevent the contact between tailings and tree roots, at least during the two growing seasons tested. The use of a thin or thick layer of mine topsoil above the thickened tailings was tested to investigate if root contact with tailings influenced tree growth. The manure (MT), compost (CT) and topsoil (ST2) application rates were calculated to provide at least $4 \%$ of organic matter and improve the thickened tailings' air-filled porosity. 
Table 1 Physio-chemical properties and trace metal concentrations of thickened tailings and amendments. Mean (SE), $N=3$. All units refer to dry matter mass

\begin{tabular}{|c|c|c|c|c|c|c|c|c|c|}
\hline & & $\begin{array}{l}\text { Mine Top- } \\
\text { soil, Non } \\
\text { Stockpiled } \\
\text { (S) }\end{array}$ & $\begin{array}{l}\text { Overburden } \\
\text { Topsoil, } \\
\text { Stockpiled } \\
\text { (OT) }\end{array}$ & $\begin{array}{l}\text { Overburden } \\
\text { Sub-soil, } \\
\text { Stock-piled } \\
\text { (OS) }\end{array}$ & $\begin{array}{c}\text { Freshly } \\
\text { Deposited } \\
\text { Thickened } \\
\text { Tailings (T) }\end{array}$ & $\begin{array}{c}\text { Compost } \\
\text { Bic } \\
\text { (C) }\end{array}$ & $\begin{array}{c}\text { Compost } \\
\text { CSH } \\
\text { (C2) }\end{array}$ & $\begin{array}{c}\text { Peat } \\
\text { (P) }\end{array}$ & $\begin{array}{c}\text { Chicken } \\
\text { Manure } \\
\text { (M) }\end{array}$ \\
\hline $\mathrm{pH}$ & & $4.6(0.0)$ & $5.1(0.1)$ & $7.2(0.1)$ & $8.0(0.1)$ & $6.8(0.1)$ & $6.4(0.1)$ & $4.2(0.0)$ & $7.3(0.0)$ \\
\hline Clay* & $\%$ & $6(0.7)$ & $42(5)$ & $33(5)$ & $12(1)$ & & & & \\
\hline Silt* & $\%$ & $22(1)$ & $27(1)$ & $15(1)$ & $50(1)$ & & & & \\
\hline OM* & $\%$ & $14(1)$ & $17(3)$ & $1.1(3)$ & $0.5(0.1)$ & $54(3)$ & $54(5)$ & $94(1)$ & $50(1)$ \\
\hline $\mathrm{C} / \mathrm{N}$ & & $27(2)$ & $22(7)$ & $17(5)$ & $15(6)$ & $21(1)$ & $28(1)$ & $41(1)$ & $6(0.1)$ \\
\hline $\mathrm{EC}^{*}$ & $\mathrm{cS} . \mathrm{m}^{-1}$ & $3(0.2)$ & & & $10(1)$ & $47(1)$ & $18(5)$ & $0.4(0.3)$ & $54(5)$ \\
\hline Total N & g.kg-1 & $3.1(0.1)$ & $4.3(0.3)$ & $0.4(0.3)$ & $0.3(0.1)$ & $15(0.4)$ & $11.4(0.9)$ & $\begin{array}{l}13.3 \\
(0.3)\end{array}$ & 47 (1) \\
\hline Total P & g. $\mathrm{kg}^{-1}$ & $0.3(0.01)$ & $0.6(0.04)$ & $0.6(0.04)$ & $0.6(0.01)$ & $4.5(0.2)$ & $1.7(0.1)$ & $\begin{array}{c}0.5 \\
(0.02)\end{array}$ & $16(0.4)$ \\
\hline P Olsen & mg.kg-1 & $11(1)$ & & & $6(2)$ & $429(48)$ & 289 (9) & $18(1)$ & 959 (12) \\
\hline Total K & g. $\mathrm{kg}^{-1}$ & $0.6(0.02)$ & $3.6(0.05)$ & $2.7(0.05)$ & $7.2(0.1)$ & $6.7(0.1)$ & $6.6(0.3)$ & $\begin{array}{c}0.3 \\
(0.02)\end{array}$ & $18(0.1)$ \\
\hline Total Ca & g.kg-1 & $2(0.1)$ & $11(1)$ & $9(1)$ & $18(0.4)$ & $78(0.4)$ & $13(0.6)$ & $4(0.1)$ & $100(4)$ \\
\hline Total Mg & g. $\mathrm{kg}^{-1}$ & $3(0.1)$ & $11(0.1)$ & $11(0.1)$ & $12(0.1)$ & $5(0.1)$ & $3(0.2)$ & $1(0.03)$ & $5(0.1)$ \\
\hline Total Na & g. $\mathrm{kg}^{-1}$ & $0.1(0.01)$ & & & $0.4(0.02)$ & $1.5(0.02)$ & $0.6(0.04)$ & $\begin{array}{c}0.1 \\
(0.01)\end{array}$ & $2.9(0.1)$ \\
\hline Total Al & g. $\mathrm{kg}^{-1}$ & $10(0.2)$ & $17(1)$ & $13(1)$ & $10(0.2)$ & $3(0.1)$ & $2(0.01)$ & $1(0.01)$ & $\begin{array}{c}0.2 \\
(0.01)\end{array}$ \\
\hline Total Fe & g. $\mathrm{kg}^{-1}$ & $15(1)$ & $27(2)$ & $24(2)$ & $29(2)$ & $3(0.3)$ & $6(0.2)$ & $2(0.1)$ & $\begin{array}{c}0.5 \\
(0.02)\end{array}$ \\
\hline Total B & mg.kg-1 & $4(0.1)$ & $6.3(0.3)$ & $3.9(0.3)$ & $6(0.3)$ & $17(0.9)$ & $8(0.4)$ & $1(0.02)$ & $18(0.5)$ \\
\hline Total Cd & $\mathrm{mg} \cdot \mathrm{kg}^{-1}$ & BDL* & $0.6(0.15)$ & $0.4(0.15)$ & BDL* & BDL* & $0.9(0.01)$ & $8.7(0.4)$ & $\mathrm{BDL}$ \\
\hline Total Cr & $\mathrm{mg} \cdot \mathrm{kg}^{-1}$ & $43(1)$ & $120(14)$ & $116(14)$ & $101(2)$ & $8(1)$ & $7(0.2)$ & $4(0.1)$ & $1(0.1)$ \\
\hline Total Cu & $\mathrm{mg} \cdot \mathrm{kg}^{-1}$ & $24(1)$ & $58(12)$ & 31 (12) & $87(5)$ & $50(1)$ & $8(0.5)$ & $215(6)$ & $53(3)$ \\
\hline Total Mn & $\mathrm{mg} \cdot \mathrm{kg}^{-1}$ & $178(6)$ & $344(26)$ & 367 (26) & $360(5)$ & $360(5)$ & 149 (18) & $55(4)$ & $355(6)$ \\
\hline Total Ni & $\mathrm{mg} \cdot \mathrm{kg}^{-1}$ & $18(1)$ & $64(7)$ & $51(7)$ & $47(1)$ & $4(0.4)$ & $18(1)$ & $7(0.6)$ & $2(0.9)$ \\
\hline Total Pb & $\mathrm{mg} \cdot \mathrm{kg}^{-1}$ & $14(0.01)$ & $22(4)$ & $13(4)$ & $14(0.01)$ & $5(0.1)$ & $3(0.4)$ & $192(10)$ & $\begin{array}{c}0.3 \\
(0.04)\end{array}$ \\
\hline Total Zn & mg.kg-1 & $20(1)$ & $83(5)$ & $62(5)$ & $60(2)$ & $160(5)$ & $22(1)$ & $104(5)$ & 338 (10) \\
\hline
\end{tabular}

* Clay: particles $<2 \mu \mathrm{m}$, silt: particles $<50 \mu \mathrm{m}, \mathrm{OM}$ : organic matter, EC: electrical conductivity, BDL: below detection limit. 
In the second glasshouse study, additional amendments were tested in mixtures with the tailings (2/3 versus $1 / 3$ by volume) and compared with tailings alone (T) (Table 1). The tailings were sampled from the tailings impoundment where they had been deposited two months previously:

- Peat (PT) (8\% DW in the mixture).

- A second vermicompost was produced from food wastes (C2T) provided by the Commission scolaire Harricana (CSH, Amos, QC) (35\% DW).

- Overburden topsoil (OTT) and subsoil (OST) scraped from above the pit and stockpiled (54\% and $67 \%$ DW, respectively).

The overburden soil was a luvic gleysol (Agriculture and Agri-Food Canada, 2010) coming from a swamp area above the pit that had been previously colonised by conifers. The soils were stockpiled for 12 to 18 months before use in $7 \mathrm{~m}$ high piles with a 2.5:1 slope. The overburden topsoil consisted of the uppermost $30 \mathrm{~cm}$ of dark (organic-rich) soil layers ( $O$ and $A$ horizons) that had been set aside prior to the excavation of the open-pit. The overburden subsoil consisted of the remaining mineral clay soil (several meters thick) that was excavated down to bedrock after the overburden topsoil had been removed. We evaluated whether the use of organic topsoil was necessary to sustain tree growth compared to mineral subsoil in the case of local clay soils, which may have good CEC and water retention properties.

The same overburden topsoil and subsoil materials were used in the field experiment over compacted waste rock. The plots had a 10:1 slope depicting the truck roads covering waste rock piles. A $50 \mathrm{~cm}$ layer was applied in July 2011, a few days before planting. Two compaction intensities were applied to the surface layer materials to determine the consequences of repeated machinery passage on tree growth: one pass vs three passes of a crawler-dozer (John Deere $850 \mathrm{~K}, 0.6 \mathrm{~kg} . \mathrm{cm}^{-2}$ ). After the three passes, the thickness of the overburden layer was decreased from 50 to $30 \mathrm{~cm}$. All trees were fertilised $(15 \mathrm{~g}$ ammonium nitrate (34.5-0-0) and $15 \mathrm{~g}$ triple superphosphate (0-45-0)) by placed fertilisation (Van den Driessche, 1999), which involved fertiliser insertion into a slit made with a spade near the base of each tree $(20 \mathrm{~cm}$ from the tree and $15 \mathrm{~cm}$ deep).

\subsection{Experimental designs}

Both glasshouse studies were set up as randomised block designs. In the first experiment, there were five replicates (blocks) of 42 trees, i.e. seven tree species (spruce, pine, tamarack, alder, hybrid poplars $M \times B$ and $\mathrm{DN} \times \mathrm{M}$, basket willow) on six substrates (T, MT, CT, ST1, ST2, S). In the second experiment, there were three replicates (blocks) of 15 trees: five substrate (T, PT, C2T, OTT, OST) $x$ three trees (pseudo-replicates).

For the waste rock experiment, a split-plot design was used: 3 blocks (replicates) $\times 4$ treatments (whole plot factor: overburden topsoil compacted or not, overburden subsoil compacted or not) $x 4$ tree species (subplot factor: jack pine, tamarack, $\mathrm{M} \times \mathrm{B}$ poplar, basket willow) $\times 16$ trees per factor combination (pseudoreplicates). The three replicate blocks consisted of $82 \times 20 \times 2 \mathrm{~m}$ (10:1 slope) compacted waste rock. Each treatment covered a $13 \times 13 \mathrm{~m}$ area and was separated from the others by a $6 \mathrm{~m}$ wide zone without soil layer. The trees were planted at $1 \times 1 \mathrm{~m}$ spacing and a $3 \mathrm{~m}$ buffer zone was kept free of trees at the edge of the soil layers.

\subsection{Measurements, sampling and analysis}

\subsubsection{Chemical analyses and texture}

Three random samples were taken at the beginning of the glasshouse experiments for tailings and amendment characterisation (Table 1). In the first glasshouse experiment, the substrates were also resampled after two growing seasons for each live tree (for ST1 treatment, only the covering topsoil was sampled). In the waste rock experiment, each analysed sample was a composite of two samples (one on top of the slope, one on the bottom of the slope) randomly collected one week after planting ( 3 blocks $x$ 4 treatments) for each $13 \times 13 \mathrm{~m}$ plot $(\mathrm{N}=12)$. 
Nutrient analyses were conducted on sieved $\left(2 \mathrm{~mm}\right.$ mesh), finely ground, oven-dried samples $\left(50^{\circ} \mathrm{C}\right)$ (Lakehead University Centre for Analytical Services, Thunderbay, ON, Canada). Total N and organic C were analysed by the Dumas combustion method (LECO CNS 2000, Mississauga, ON). Organic matter concentrations were calculated as $1.72 \times$ organic carbon (C). Following $\mathrm{HNO}_{3}-\mathrm{HCl}$ digestion, sample concentrations of total $\mathrm{P}, \mathrm{K}, \mathrm{Ca}, \mathrm{Mg}, \mathrm{Na}, \mathrm{Al}, \mathrm{As}, \mathrm{B}, \mathrm{Ba}, \mathrm{Be}, \mathrm{Cd}, \mathrm{Co}, \mathrm{Cr}, \mathrm{Cu}, \mathrm{Fe}, \mathrm{Mn}, \mathrm{Mo}, \mathrm{Ni}, \mathrm{Pb}, \mathrm{S}, \mathrm{Se}$, Sr, and TI were determined by inductively coupled plasma-atomic emission spectrometry (ICP-AES, Vista PRO, Varian Canada, Mississauga, ON). Available-P was determined in a sodium bicarbonate solution using spectrophotometry (Olsen et al., 1954). Exchangeable Fe, $\mathrm{Mn}, \mathrm{Cu}, \mathrm{Al}$ and $\mathrm{Zn}$ were extracted in DPTA and also determined by ICP-AES. Finally, $\mathrm{pH}$ was determined in a saturated paste extract and electrical conductivity in $1: 2$ water solution. After drying $\left(50^{\circ} \mathrm{C}\right)$, plant leaves and fine roots from the first glasshouse experiment were analysed for total $\mathrm{N}, \mathrm{P}, \mathrm{Ca}, \mathrm{Mg}$ and $\mathrm{K}$, together with the same total metals as were determined for the rooting substrates, using the previously detailed analytical methods. Soil texture was determined using the Bouyoucos hydrometer method (Bouyoucos, 1962).

\subsubsection{Substrate structure}

In the glasshouse experiments, undisturbed $100 \mathrm{~cm}^{3}$ soil samples were taken with a double cylinder soil sampler in three pots for each substrate. These pots were prepared without plants and watered for two weeks before sampling. In the waste rock experiment, four samples by treatment (one per species) were collected with the same technique (48 samples). Bulk density and macroporosity (air-filled porosity, \% of pores $<50 \mu \mathrm{m}$ ) were determined following procedures outlined by Cassel and Nielsen (1986). Soil mechanical resistance was measured with an Effegi hand-held penetrometer pressed against the soil (Facchini, Alfonsine, Italy; accuracy $\pm 1 \% ; 2.54 \mathrm{~mm}$ probe).

\subsubsection{Growth and biomass assessments}

In the first glasshouse experiment, survival, stem height, and basal diameter were measured at planting and at the end of each growing season. In the second glasshouse experiment, survival was measured prior to plant harvest. The trees were separated into foliage, stems, and fine (diameter $<1 \mathrm{~mm}$ ) and coarse roots. The different plant parts were oven-dried at $50^{\circ} \mathrm{C}$ to constant mass and weighed.

\subsubsection{Statistical analyses}

Survival data were compared using the $\chi 2$ test (PROC FREQ, SAS V.9.2, SAS Institute Inc., Cary, NC). For substrate characteristics, height and diameter increments, biomass, and plant element concentrations, the data were submitted to two-way analyses of variance (treatment, species) (PROC GLM or MIXED). Height and basal diameter were subjected to three-way analyses of variance (date, substrate, and species) (PROC MIXED, with repeated measures) in experiment 1. All tested factors were fixed effects and the block factor was considered a random effect. When effects were significant for a given variable, least-square means were estimated (LS MEANS statement) and Tukey tests were conducted to separate the means. Pearson product-moment correlations $(r)$ were calculated between substrate characteristics and tree growth parameters (PROC CORR). Overall significance for analyses was set to alpha $=0.05$.

\section{$3 \quad$ Results}

\subsection{Trees in tailings}

In the first glasshouse study, all trees that had been planted in tailings (fertilised with NPK or manure) died by the end of the first growing season (Table 2.1). However in the second glasshouse experiment, the $\mathrm{DN} \times \mathrm{M}$ poplar survived in tailings alone (Table 2.2). In both experiments, tailings appeared to have bulk density higher than 1.24 and air-filled porosity lower than $8 \%$ (Table 3.1 and 3.2), which may impede tree root growth. Indeed, tree roots never developed in the tailings below the thin topsoil layer in the first glasshouse study. 
Table 2 Percentages of tree survival among treatments at the end of the experiments for each species

\begin{tabular}{|c|c|c|c|c|c|c|c|c|c|c|c|}
\hline \multirow[b]{2}{*}{ Name } & \multicolumn{6}{|c|}{ 1st Experiment $(\mathrm{N}=5)$} & \multicolumn{5}{|c|}{ 2nd Experiment $(\mathrm{N}=9)$} \\
\hline & $\mathbf{T}$ & $\mathbf{S}$ & ST1 & ST2 & MT & CT & $\mathbf{T}$ & C2T & PT & OTT & OST \\
\hline DN×M Poplar & 0 & 100 & 100 & 100 & 0 & 20 & 89 & 89 & 56 & 44 & 22 \\
\hline M×B Poplar & 0 & 60 & 100 & 20 & 0 & 0 & & & & & \\
\hline Willow & 0 & 100 & 100 & 100 & 0 & 20 & & & & & \\
\hline Alder & 0 & 80 & 100 & 40 & 0 & 0 & & & & & \\
\hline Spruce & 0 & 100 & 100 & 100 & 0 & 40 & & & & & \\
\hline Pine & 0 & 100 & 100 & 100 & 0 & 60 & & & & & \\
\hline Tamarack & 0 & 80 & 100 & 100 & 0 & 100 & & & & & \\
\hline
\end{tabular}

Table 3 Bulk density, air-filled porosity, $\mathrm{pH}$, electrical conductivity, and mechanical resistance among treatments at the beginning of the experiments. 1) first glasshouse experiment; 2) second glasshouse experiment, and 3) waste rock experiment - Mean (SE). $\mathbf{N}=3$ to 5 . Treatments with the same letter do not differ at the 0.05 level $(a<b)$

\begin{tabular}{|c|c|c|c|c|c|c|}
\hline & & $\begin{array}{l}\text { Bulk Density } \\
\left(\mathrm{g} \cdot \mathrm{cm}^{-3}\right)\end{array}$ & $\begin{array}{c}\text { Air-filled } \\
\text { Porosity } \\
\text { (\%) }\end{array}$ & $\mathrm{pH}$ & $\begin{array}{c}E C \\
\left(\mathrm{cS} \cdot \mathrm{m}^{-1}\right)\end{array}$ & $\begin{array}{c}\text { Mechanical } \\
\text { Resistance } \\
\left(\mathbf{k g} \cdot \mathrm{cm}^{-2}\right)\end{array}$ \\
\hline \multirow[t]{6}{*}{ 1) } & T: Tailings & $1.24(0,04) b$ & $8(0.1) a$ & $8.0(0.1) c$ & $10(1) b$ & \\
\hline & S: Topsoil & $0.63(0.01) a$ & $28(1.1) \mathrm{b}$ & $4.6(0.02) a$ & $3(0.2) a$ & \\
\hline & ST1: Thin topsoil layer above tailings & $0.61(0.02) a$ & $26(0.5) b$ & $4.6(0.02) a$ & $3(0.2) a$ & \\
\hline & ST2: Topsoil mixed with tailings & $0.98(0.04) b$ & $10(1.1) a$ & $7.2(0.01) b$ & $9(1) \mathrm{b}$ & \\
\hline & MT: Tailings and manure & $1.26(0.1) b$ & $6(0.2) \mathrm{a}$ & $8.2(0.1) c$ & $15(1) c$ & \\
\hline & CT: Bic Compost mixed with tailings & $0.69(0.03) a$ & $20(1.1) b$ & $7.0(0.01) b$ & $34(1) d$ & \\
\hline \multirow[t]{5}{*}{ 2) } & T: Tailings & $1.42(0.04) d$ & $7.1(1.5) a$ & $7.7(0.2) a b$ & $14(2) b$ & \\
\hline & PT: Peat mixed with tailings & $0.58(0.05) a$ & $27(1.5) d$ & $7.7(0.2) a b$ & $9(1.5) \mathrm{a}$ & \\
\hline & C2T: Amos Compost mixed with tailings & $0.69(0.05) a b$ & $17(1.5) c$ & $7.2(0.2) a$ & $40(1.5) c$ & \\
\hline & OTT: Overburden topsoil mixed with tailings & $0.99(0.05) c$ & $12(1.5) b$ & $7.9(0.2) b$ & $8(1.5) a$ & \\
\hline & OST: Overburden subsoil mixed with tailings & $1.31(0.05) \mathrm{d}$ & 11 (1.5)ab & $8.1(0.2) b$ & $5(1.5) a$ & \\
\hline \multirow[t]{4}{*}{ 3) } & Overburden topsoil, not-compacted & $0.78(0.01) \mathrm{a}$ & $12(2.5) a$ & $5.1(0.08) a$ & & $14(1.2) \mathrm{a}$ \\
\hline & Overburden topsoil, compacted & $0.73(0.01) \mathrm{a}$ & $12(2.7) a$ & $5.1(0.08) a$ & & $19(1.2) b$ \\
\hline & Overburden subsoil, not-compacted & $1.39(0.01) \mathrm{b}$ & $8(2.5) a$ & $7.2(0.08) b$ & & $31(1.2) c$ \\
\hline & Overburden subsoil, compacted & $1.36(0.01) b$ & $10(2.5) \mathrm{a}$ & $7.2(0.08) b$ & & $41(1.2) \mathrm{d}$ \\
\hline
\end{tabular}




\subsection{Tree growth in tailings mixed with amendments}

Mixing mine soils with tailings resulted in air-filled porosity values between 10 and $12 \%$ (Table 3.1 and 3.2), even if the two topsoils that were used had organic matter concentrations higher than $14 \%$ (Table 1). Consequently, DN $\times M$ poplar survival was lower than $44 \%$ in overburden topsoil or subsoil mixed with tailings (exp. 2, Table 2.2). In topsoil mixed with tailings (exp. 1), conifer total and leaf biomass, together with broad-leaved tree height growth during the first growing season, decreased on this treatment compared to topsoil alone (Figure 1(1) and 1(3)).
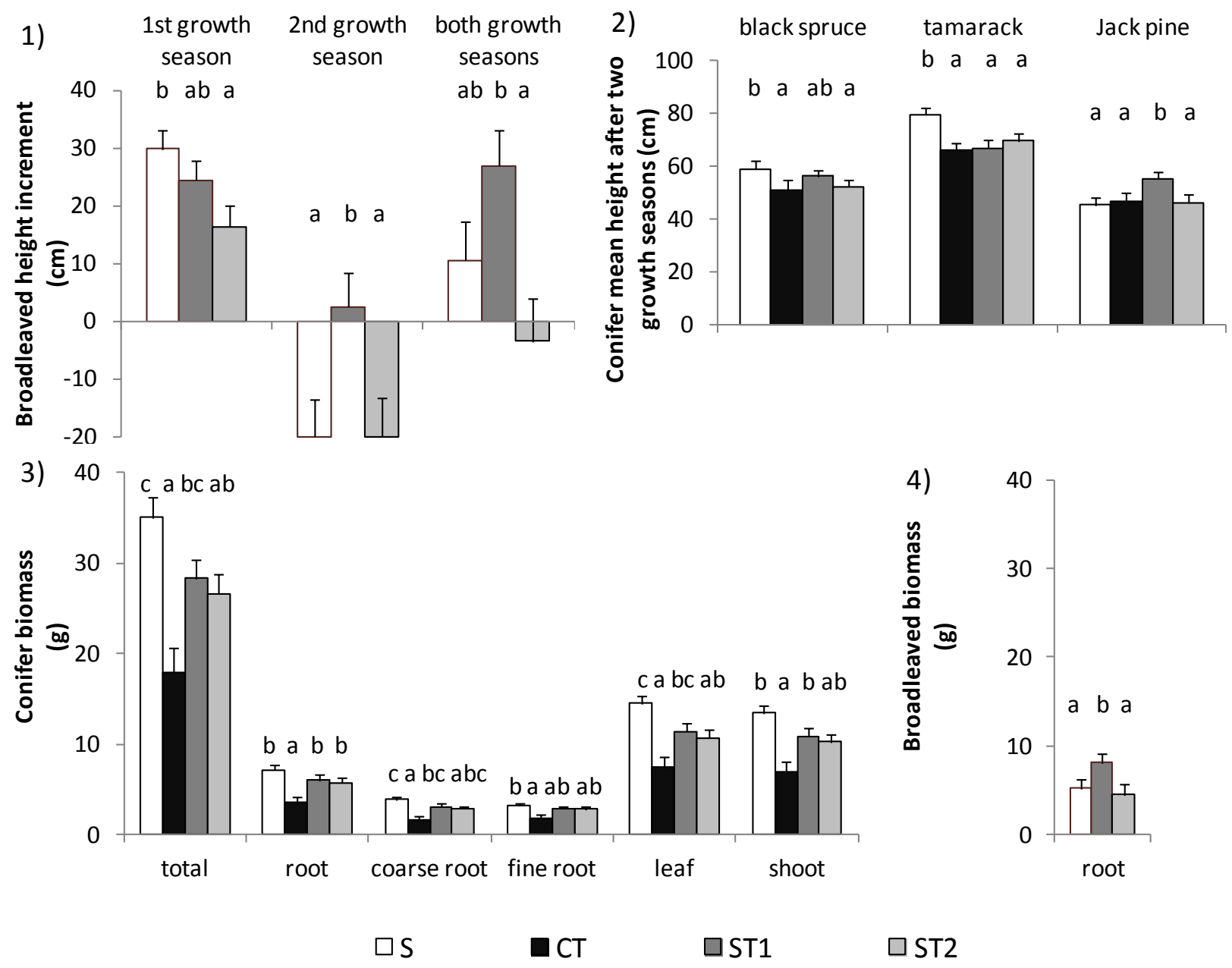

Figure 1 Tree height growth and biomass among treatments (S: topsoil; CT: compost Bic mixed with thickened tailings; ST1: thin topsoil layer above thickened tailings; ST2: topsoil mixed with thickened tailings) in the first glasshouse experiment. 1) Broad-leaved height increments along the experiment; 2) Conifer mean height at the end of the experiment; 3) Conifer and 4) Broadleaved biomasses at the end of the experiment. Mean $\pm S E, N=3$ to 5 . Treatment means that do not differ at the 0.05 level share the same letter $(a<$ b $<$ c)

In contrast, the mixing of tailings with compost or peat increased air-filled porosity above $17 \%$, with the most efficient amendment being peat, which conferred the greatest air-filled porosity to the mixtures (27\%) while having the lowest organic matter concentration (8\%). Compost mixtures also exhibited electrical conductivities higher than $34 \mathrm{cS} . \mathrm{m}^{-1}$ (Table 3.1 and 3.2). Consequently, in the CT treatment (exp. 1), almost all broad-leaved trees died and survival rates were decreased for spruce and pine (Table 2.1), as well as were conifer biomasses (Figure 1.3). 
Trace metal absorption by the trees was limited in the mixtures, probably due to the near-neutral $\mathrm{pH}$ conferred by the tailings (Tables 3.1 and 3.2). Only black spruce and basket willow accumulated Mn (slightly above $300 \mathrm{mg} \cdot \mathrm{kg}^{-1}$ ) in the leaves and roots, respectively.

\subsection{Tree growth in mine soil layers}

\subsubsection{Overburden soil layers above waste rock (exp.3)}

Tree survival in all treatments was greater than $96 \%$, except in one plot with uncompacted subsoil layer, where it decreased to $70 \%$. At the conclusion of the first growing season, trees in overburden topsoil covering waste rock were bigger (broad-leaved tree height and diameters of all species) than those grown in overburden subsoil (Figure 2). As both treatments received $\mathrm{N}$ and $\mathrm{P}$ mineral fertilisation, this result may be due to structural differences between the two top layers. Indeed, the subsoil had greater bulk density and mechanical resistance than the topsoil (Table 3.3), which could have hindered root development.
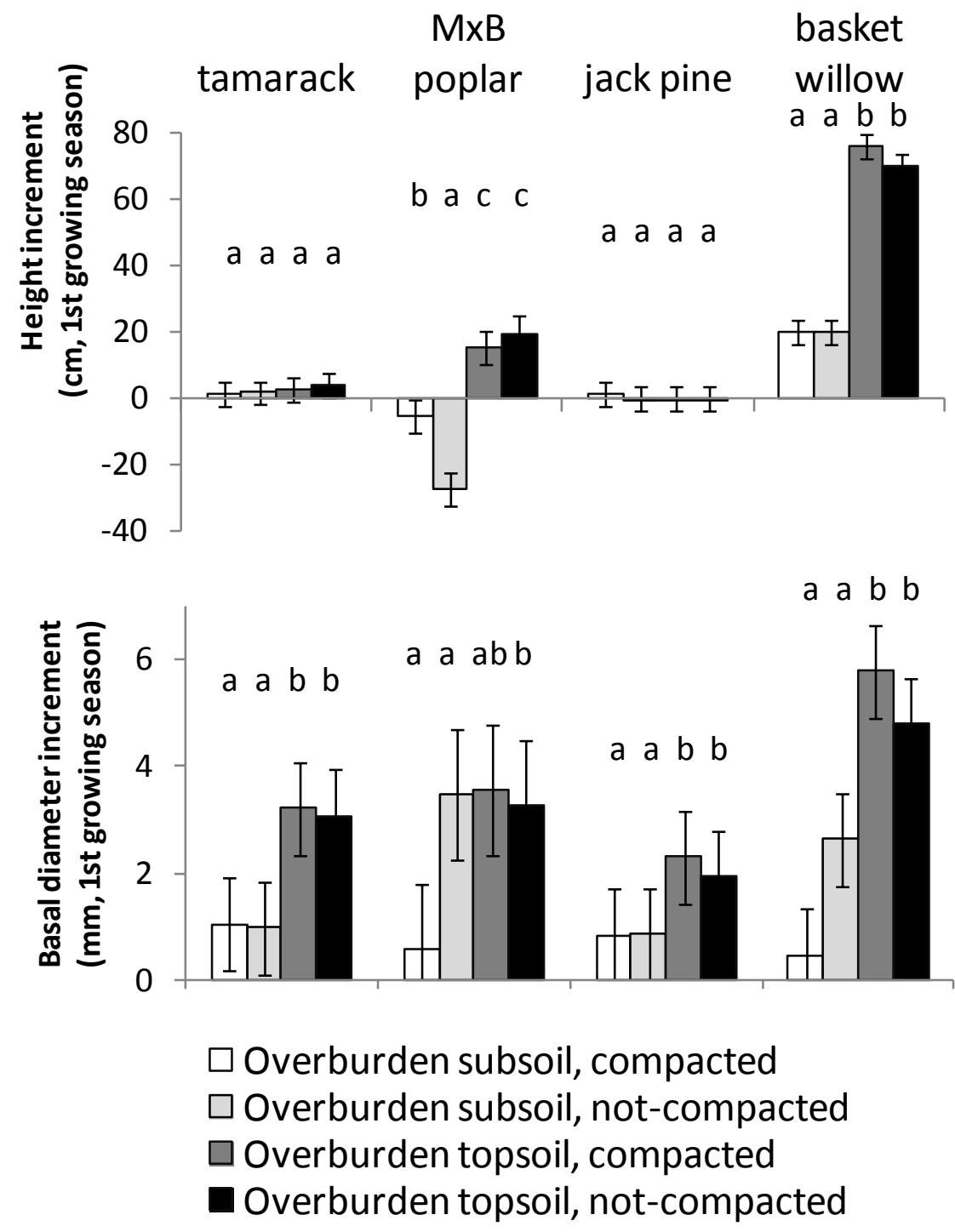

Figure 2 Height and basal diameter increments after the first growing season for each planted species among the four layers applied on waste rock: overburden subsoil, compacted vs uncompacted; and overburden topsoil, compacted vs uncompacted. Mean $\pm S E, \mathbf{N}=48$. Treatments that do not differ at the 0.05 level share the same letter $(a<b<c)$ 
The compaction treatment had no measurable effect on soil layer macroporosity or bulk density (Table 3.3) over the short-term, nor did it affect tree survival and growth. Its only effect was to increase mechanical resistance of the substrate under dry conditions (Table 3.3). Increased resistance in the topsoil was half that of the subsoil.

\subsubsection{Metal absorption in topsoil layers above thickened tailings}

The low pH (4.6) of the topsoil used in the first glasshouse experiment (Table 3.1) enhanced metal bioavailability, but tree survival was not affected (Table 2.1). In both S and ST1 treatments, topsoil concentrations of extractable Al (in DPTA) were negatively correlated with root biomass $(p<0.05 ; r=-0.46$ for total root biomass, $r=-0.57$ for coarse root biomass) for all tree species. Further, several tree species grown in the $\mathrm{S}$ treatment accumulated $\mathrm{Mn}$ or $\mathrm{Zn}$ in their leaves at concentrations above reported phytotoxic levels (Table 4). Interestingly, after two growing seasons, the $\mathrm{pH}$ of the topsoil covering thickened tailings $(S T 1,5.8)$ had significantly increased $(p<0.001)$ compared to the topsoil alone $(S, 5.5)$, probably due to the alkaline influence of the tailings. Consequently, $\mathrm{Zn}$ and $\mathrm{Mn}$ accumulation decreased in the leaves of several species in the ST1 treatment, as did DTPA-Al concentrations (Table 4). In ST1 treatment, where $\mathrm{Al}, \mathrm{Zn}$, and $\mathrm{Mn}$ phytotoxicity had decreased, both tree height growth (broad-leaved species and jack pine) and root biomass (broad-leaved trees) improved when compared to the $S$ treatment (Figure 1.1, 1.2 and 1.4). However, trees also accumulated $\mathrm{Cu}\left(>100 \mathrm{mg}^{\mathrm{k}} \mathrm{kg}^{-1}\right)$ beyond reported phytotoxic levels in their fine roots in the ST1 treatment relative to other treatments (Table 4).

Table 4 Metal concentrations in tree leaves and fine roots among treatments. Mean (SE), $N=3$ to 5 . Treatments that do not differ at the 0.05 level share the same letter in each row $(a<b<c)$

\begin{tabular}{|c|c|c|c|c|c|c|}
\hline & & $\begin{array}{l}\text { Topsoil } \\
\text { (S) }\end{array}$ & $\begin{array}{l}\text { Topsoil } \\
\text { Above } \\
\text { Thickened } \\
\text { Tailings } \\
\text { (ST1) }\end{array}$ & $\begin{array}{l}\text { Topsoil } \\
\text { Mixed with } \\
\text { Thickened } \\
\text { Tailings } \\
\text { (ST2) }\end{array}$ & $\begin{array}{l}\text { Compost } \\
\text { Mixed } \\
\text { with } \\
\text { Thickened } \\
\text { Tailings } \\
\text { (CT) }\end{array}$ & $\begin{array}{l}\text { Phytotoxicity } \\
\text { Thresholds in } \\
\text { Plants (Kabata- } \\
\text { Pendias and } \\
\text { Pendias, 2001) }\end{array}$ \\
\hline DTPA-Al & & $87(3) c$ & $67(3) b$ & $5(3) a$ & $1(0.2) a$ & \\
\hline \multirow[t]{5}{*}{ Mn (leaves) } & Black spruce & $703(58) b$ & 492 (58)ab & 323 (58)a & 197 (95)a & $300-500 \mathrm{mg} \cdot{ }^{\mathrm{kg}-1}$ \\
\hline & Tamarack & $385(66) b$ & $443(58) b$ & $95(58) a$ & $24(58) a$ & \\
\hline & Jack pine & $330(77) b$ & $284(77) b$ & $91(58) a$ & 37 (77)a & \\
\hline & Green alder & $410(41) c$ & $214(36) b$ & 55 (59)a & & \\
\hline & Basket willow & $502(36) a$ & $459(36) a$ & $332(41) a$ & & \\
\hline \multirow[t]{3}{*}{ Zn (leaves) } & $\begin{array}{l}\text { M×B hybrid } \\
\text { poplar }\end{array}$ & $462(37) c$ & $230(32) b$ & $87(32) a$ & & $100-400 \mathrm{mg} \cdot{ }^{\mathrm{kg}-1}$ \\
\hline & $\begin{array}{l}\mathrm{DN} \times \mathrm{M} \text { hybrid } \\
\text { poplar }\end{array}$ & $368(28) b$ & $291(28) b$ & $33(28) a$ & & \\
\hline & Basket willow & $298(28) c$ & $207(28) b$ & $85(32) a$ & & \\
\hline \multirow[t]{3}{*}{$\begin{array}{l}\mathrm{Cu} \text { (fine } \\
\text { roots) }\end{array}$} & $\begin{array}{l}\text { Broad-leaved } \\
\text { trees }\end{array}$ & $22(7) a$ & $106(7) c$ & $53(8) b$ & & $15-100 \mathrm{mg} .{ }^{\mathrm{kg}-1}$ \\
\hline & Tamarack & 36 (11)a & $127(10) b$ & 47 (10)a & 46 (10)a & \\
\hline & Jack pine & 11 (10)a & $114(10) b$ & $29(10) a$ & 38 (13)a & \\
\hline
\end{tabular}




\section{Discussion}

Interestingly, the presence of alkaline thickened tailings below a thin topsoil layer improved tree height growth and root biomass compared to topsoil alone. Tailings increased the $\mathrm{pH}$ of the topsoil layer, which decreased $\mathrm{Zn}$ and $\mathrm{Mn}$ accumulation that had been observed in the leaves of several broad-leaved trees as well as Al impeding root growth. The growth increase occurred despite a 1/3-reduced soil volume for root exploration because roots did not penetrate the thickened tailings layer. As topsoils of surface mines are frequently acidic (Hutnik and McKee, 1990) and may be contaminated by metals (in the case of metalliferous mines), this result demonstrates that the use of a thin topsoil layer above alkaline thickened tailings could provide a better plantation yield than the use of a thicker and more expensive layer.

The low $\mathrm{pH}$ of the topsoil that was used induced Al toxicity effects in tree roots, as shown by a negative correlation between root growth and DTPA-Al concentrations for broad-leaved species. These results are in accordance with Al toxicity effects reported for plants, especially plant roots, when soil pH is lower than 4.5-5 (Andersson, 1988; Delhaize and Ryan, 1995), and even 5.5 in minespoils (Rout et al., 2001). The use of a thin topsoil layer had opposite effects for Cu concentrations compared to those of $\mathrm{Al}, \mathrm{Zn}$, and $\mathrm{Mn}$. Indeed, $\mathrm{Cu}$ accumulated (Table 4) in the roots of all tree species, except for spruce grown in ST1. However, tree growth and survival were maximal on this treatment and Cu levels were normally low in leaves, due to the restricted transport of this element from roots to leaves (Wisniewski and Dickinson, 2003). The Cu may originate from $\mathrm{CuSO}_{4}$ that had been added to the tailings to accelerate the cyanide destruction reaction.

Despite elevated concentrations in trees grown in the topsoil, metal toxicity was likely limited because the boreal species that were used may be well-adapted to acidic soils (Timoney et al., 1993) and to associated Al (Hutchinson et al., 1986) and other metal toxicity. Indeed, trees grown on the topsoil (S and ST1 treatments) had very good survival. Moreover, although Al toxicity generally induces $\mathrm{P}$ and Ca deficiencies in tree leaves (Andersson, 1988; Delhaize and Ryan, 1995; Rout et al., 2001), black spruce and tamarack had needle $P$ and Ca concentrations above the requirements reported in literature (Martin-Prével et al., 1978).

However the relevance of using thin topsoil layers to maximise the beneficial effect of underlying alkaline tailings on metal phytotoxicity may be lessened by impeded development of tree roots in the tailings. Indeed, appropriate anchorage of tree roots appears essential for the long-term sustainability of plantations. The low air-filled porosity of thickened tailings (6\% in T and $8 \%$ in MT) likely resulted in oxygen shortages for root respiration and subsequent tree death in the first glasshouse experiment. Archer and Smith (1972) reported a threshold below which plant growth decreased when soil air capacity is less than $10 \%$ by volume. Similar anaerobiosis problems can occur in fine-textured soils of natural environments (Tisdall and Hodgson, 1990). In the second glasshouse experiment however, the tailings were allowed to drain and form cracks between two watering events, providing additional aeration for root growth. Also, the small volume of the cells $\left(110 \mathrm{~cm}^{3}\right)$ may have enhanced $\mathrm{O}_{2}$ turnover. Consequently, the test poplars survived over the short-term ( 5 weeks) and developed some roots in the tailings. It is thus possible that natural drainage under field conditions would improve thickened tailing aeration and root penetration under the soil layers, especially in the elevated portions of the tailing impoundments. Yet thickened tailings may lose a great proportion of their water through evaporation rather than gravity, and the former may be limited by the use of soil layers. These questions will be answered by a third experiment established in spring 2012 on in situ tailings deposited six months before planting.

In the case of the overburden soils that were used to cover waste rock, the compaction treatment imposed by the crawler-dozer had no effect on soil macroporosity and density, contrary to our expectations. The soils were very likely already highly compacted by the transport and stockpiling conditions (Ramsay, 1986). The stockpiled subsoil reached density and mechanical resistance thresholds $\left(1.4 \mathrm{~kg} . \mathrm{cm}^{-2}\right.$ for density, according to Schuurman (1965); and $30 \mathrm{~kg} . \mathrm{cm}^{-2}$ for mechanical resistance, according to Hakansson and Lipiec (2000), Table 3.3) that very likely decreased tree root growth. In large open-pit mines, digging the pit implies the removing of great soil quantities which must be stockpiled in limited space until the tailings impoundments and waste rock piles are ready for revegetation. To alleviate the negative effects of 
stockpiling on the overburden subsoil structure, mixing it with an organic matter-rich amendment should be tested to ascertain whether its structural quality can be improved.

Yet the OM-rich overburden topsoil (17\%) was more resistant than the mineral subsoil to compaction effects on mechanical resistance, the increase of which was reduced by half compared to the increase in the mineral subsoil. Soane (1990) noted that the presence of organic matter increases soil elasticity and resistance to deformation and, thus, decreases compactibility. Consequently, tree growth was improved on this substrate compared to the subsoil (Figure 2).

Compared to soil layers, the interest of using mixtures of thickened tailings with amendments lies in reducing metal absorption by trees from the substrates due to the neutral $\mathrm{pH}$ of the mixtures (De Nicola et al., 2003). No metal accumulation in the leaves of trees that had been grown in mixtures was encountered in the first glasshouse experiment. However, tree survival and growth may be limited by inadequate airfilled porosity or salinity of the mixtures.

Mixing tailings with mine topsoil (ST2) or overburden soils (OTT and OST) kept air-filled porosity (Table 3) close to the 10\% threshold necessary to allow root growth (Archer and Smith, 1972). When the soils were stockpiled (exp. 2), DN×M hybrid poplar survival was low (Table 2.2). Conversely, in experiment 1, the sandy texture of the topsoil and the soil organisms kept alive without stockpiling (Abdul-Kareem and McRae, 1984) probably played an active role in improving drainage and restoring soil air-filled porosity, respectively. Consequently, trees had high survival, but their growth and biomass were decreased (Figure 1).

On one hand, the use of vermicompost (CT and C2T) successfully increased air-filled porosity to levels suitable for root growth (Table 3). Earthworm compost is known to provide humic acid substances (Canellas et al., 2002), which form stable aggregates by adhesion with substrate particles that increase porosity (Ibrahim and Goh, 2004). However, peat and its fibrous texture appeared to be the most efficient amendment for alleviating the low air-filled porosity of the tailings.

On the other hand, composts from food wastes appeared to be inadequate for establishing tree plantations on tailings. Their use greatly increased electrical conductivity of the mixtures to values near or above the $40 \mathrm{cS} . \mathrm{m}^{-1}$ threshold that allows root survival (Epstein et al., 1976; Jordan et al., 2008). High salt concentrations lead to high osmotic potentials in the substrate, limiting the availability of water for tree roots and possibly increasing drought stress (Jordan et al., 2008). In the short-term, elevated salinity had no deleterious effects on the growth and survival of poplar trees in experiment 2. Over the longer term, however, all broad-leaved trees died in the first glasshouse experiment, while conifer trees, which transpire less (Bugmann, 1996) and are generally more drought tolerant than broad-leaved species (Gao et al., 2002), survived but showed decreases in all studied biomass parameters. These results differ from the compostenhancing effects reported in the literature when these materials are added to tailings (Mendez and Maier, 2008).

\section{Conclusion}

The main factor that limited tree plantation success in this study was the limited air-filled porosity of the fine-textured tailings on one hand and of the stockpiled mineral clay soil on the other hand. The lack of structure and drainage resistance of thickened tailings limit $\mathrm{O}_{2}$ diffusion, which may impede root growth, especially in the lower parts of tailings impoundments. The presence of organic matter in the clay soil increased its resistance to stockpiling deleterious effects on mechanical resistance and density.

Alkaline thickened tailings that are mixed with organic amendments such as peat should provide sufficient air-filled porosity and support satisfactory tree growth while limiting metal contamination. High salinity composts could be used with drought resistant conifers but at the cost of reduced growth and associated delayed improvement of the landscape.

Finally, this study demonstrated that the presence of alkaline thickened tailings under a thin acidic topsoil layer can improve tree growth compared to the use of a thick layer. This technique may accelerate 
landscape reclamation while decreasing the costs. However, as tree roots may not penetrate the thickened tailings, tree anchorage may be limited over the longer term.

\section{Acknowledgements}

This research was financed by the Osisko Mining Corporation and the Industrial R\&D Fellowship (IRDF) program of the Natural Sciences and Engineering Research Council of Canada (NSERC). The authors thank the Université du Québec en Abitibi-Témiscamingue for providing laboratory and technical equipment, as well as the Ferme Richard in Rivière-Héva, QC, and the Commission Scolaire Harricana, Amos, QC. We also thank William F.J. Parsons from the Center for Forest Research for English improvement.

\section{References}

Abdul-Kareem, A.W. and McRae, S.G. (1984) The effects on topsoil of long-term storage in stockpiles, Plant and Soil Journal, Vol. 76, pp. 357-363.

Agriculture and Agri-Food Canada (11/06/2010) The Canadian system of soil classification, 3rd edition, viewed 5 July 2012 , http://sis.agr.gc.ca/cansis/taxa/cssc3/intro.html.

Andersson, M. (1988) Toxicity and tolerance of aluminium in vascular plants, Water, Air, and Soil Pollution, Vol. 39, pp. 439-462.

Angel, P.N., Graves, D.H., Barton, C., Warner, R.C., Conrad, P.W., Sweigard, R.G. and Agouridis, C. (2006) Surface mine reforestation research: evaluation of tree response to low compaction reclamation techniques, in Proceedings of the 7 th International Conference on Acid Rock Drainage (ICARD), R.I. Barnhisel (ed), March 26-30, St. Louis, MO, Published by the American Society of Mining and Reclamation (ASMR), Lexington, KY, pp. 45-58.

Anterrieu, O., Chouteau, M. and Aubertin, M. (2010) Geophysical characterization of the large-scale internal structure of a waste rock pile from a hard rock mine, Bulletin of Engineering Geology and the Environment, Vol. 69(4), pp. 533-548.

Archer, J.R. and Smith, P.D. (1972) The relation between bulk density, available water capacity, and air capacity of soils, Journal of Soil Science, Vol. 23(4), pp. 475-480.

Bouyoucos, G.J. (1962) Hydrometer method improved for making particle-size analysis of soils, Agronomy Journal, Vol. 54, pp. 464465.

Bugmann, H. (1996) Functional types of trees in temperate and boreal forests: classification and testing, Journal of Vegetation Science, Vol. 7(3), pp. 359-370.

Burger, J.A. and Zipper, C.E. (2002) How to restore forests on surface-mined land, Reclamation guidelines for surface mined land in Southwest Virginia, Virginia Cooperative Extension, Powell River Series, Publication 460-123, 18pp.

Bussière, B. (2007) Colloquium 2004: Hydrogeotechnical properties of hard rock tailings from metal mines and emerging geoenvironmental disposal approaches, Canadian Geotechnical Journal, Vol. 44, pp. 1019-1052.

Canellas, L.P., Olivares, F.L., Okorokova-Façanha, A.L. and Façanha, A.R. (2002) Humic acids isolated from earthworm compost enhance root elongation, lateral root emergence, and plasma membrane H+-ATPase activity in maize roots, Plant Physiology, Vol. 130, pp. 1951-1957.

Cassel, D.K. and Nielsen, D.R. (1986) Field capacity and available water capacity, Methods of soil analysis, Part 1 - Physical and mineralogical methods, A. Klute (ed), Agronomy Series No. 9, ASA and SSSA, Madison, WI, USA, pp. 901-926.

Delhaize, E. and Ryan, P.R. (1995) Aluminium toxicity and tolerance in plants, Plant Physiology 107, pp. 315-321.

De Nicola, F., Maisto, G. and Alfani, A. (2003) Assessment of nutritional status and trace element contamination of holm oak woodlands through analyses of leaves and surrounding soils, Science of the Total Environment, Vol. 311, pp. 191-203.

Drake, L. (1986) Survival and growth of conservation shrubs and trees with thin-cover reclamation on acid substrate, lowa, USA, Environmental Geochemistry and Health, Vol. 8(3), pp. 62-67.

Emerson, P., Skousen, J. and Ziemkiewicz. P. (2009) Survival and growth of hardwoods in brown versus gray sandstone on a surface mine in West Virginia, Journal of Environmental Quality, Vol. 38, pp. 1821-1829.

Environment Canada (2004) National climate archives, viewed 26 April 2012, http://climate.weatheroffice.ec.gc.ca/index.html.

Epstein, E., Taylor, J.M. and Chaney, R.L. (1976) Effects of sewage sludge and sludge compost applied to soil on some soil physical and chemical properties, Journal of Environmental Quality, Vol. 5, pp. 422-426.

Gao, Q., Zhao, P., Zheng, X., Cai, X. and Shen, W. (2002) A model of stomatal conductance to quantify the relationship between leaf transpiration, microclimate and soil water stress, Plant, Cell and Environment, Vol. 25(1), pp. 1373-1381.

Hakansson, I. and Lipiec, J. (2000) A review of the usefulness of relative bulk density values in studies of soil structure and compaction, Soil and Tillage Research, Vol. 53, pp. 71-85.

Halofsky, J.E. and McCormick, L.H. (2005) Effects of unseeded areas on species richness of coal mines reclaimed with municipal biosolids, Restoration Ecology, Vol. 13(4), pp. 630-638.

Hutchinson, T.C., Bozic, L. and Munoz-Vega, G. (1986) Response of five species of conifer seedlings to aluminium stress, Water, Air, and Soil Pollution, Vol. 31, pp. 283-294.

Hutnik, R.J. and McKee, G.W. (1990) Revegetation, Surface mining (2nd edition), B.A. Kennedy (Ed.), Colorado Society for Mining, Metallurgy and Exploration, Denver, pp. 811-817.

Ibrahim, S.M. and Goh, T.B. (2004) Changes in macroaggregation and associated characteristics in mine tailings amended with humic substances, Communications in Soil Science and Plant Analysis, Vol. 35(13\&14), pp. 1905-1922. 
Jordan, S.N., Mullen, G.J. and Courtney, R.G. (2008) Utilization of spent mushroom compost for the revegetation of lead-zinc tailings: Effects on physico-chemical properties of tailings and growth of Lolium perenne, Bioresource Technology, Vol. 99, pp. 8125-8129.

Kabata-Pendias, A. and Pendias, H. (2001) Trace elements in soil and plants, 3rd edition, CRC Press, Boca Raton, Florida, 331 pp.

Kost, D.A. and Vimmerstedt, J.P. (1994) Ground cover and tree growth on calcareous mine soils: greater influence of soil surface than nitrogen rate or seed mix, in Proceedings of the International Land Reclamation and Mine Drainage Conference and the 3rd International Conference on the Abatement of Acidic Drainage, Pittsburgh, PA, April 24-29, pp. 295-304.

Martin-Prével, P. (1978) Rôle des éléments minéraux chez les végétaux, Fruits, Vol. 33(7-8), pp. 521-529.

Mendez, M.O. and Maier, R.M. (2008) Phytostabilization of mine tailings in arid and semiarid environments - an emerging remediation technology. Environmental Health Perspectives, Vol. 116(3), pp. 278-283.

Olsen, S.R., Cole, C.V., Watanave, F.S. and Dean, L.A. (1954) Estimation of available phosphorus in soils by extraction with sodium bicarbonate, Circ. USDA. 939, pp. 1-19.

Parrotta, J.A., Turnbull, J.W. and Jones, N. (1997) Catalyzing native forest regeneration on degraded tropical lands, Forest Ecology and Management, Vol. 99, pp. 1-7.

Poisson, J., Chouteau, M., Aubertin, M. and Campos, D. (2009) Geophysical experiments to image the shallow internal structure and the moisture distribution of a mine waste rock pile, Journal of Applied Geophysics, Vol. 67(2), pp. 179-192.

Ramsay, W.J.H. (1986) Bulk soil handling for quarry restoration, Soil Use and Management, Vol. 2, pp. 30-39.

Robinsky, E., Barbour, S.L., Wilson, G.W., Bordin, D. and Fredlund, D.G. (1991) Thickened sloped tailings disposal - an evaluation of seepage and abatement of acid drainage, in Proceedings of the 2nd International Conference on the Abatement of Acidic drainage, September 16-18, Montréal, QC, pp. 529-549.

Rout, G.R., Samantaray, S. and Das, P. (2001) Aluminium toxicity in plants: a review, Agronomie, Vol. 21, pp. 3-21.

Schuurman, J.J. (1965) Influence of soil density on root development and growth of oats, Plant and Soil, Vol. 22(3), pp. 352-374.

Skousen, J., Ziemkiewicz, P. and Venable, C. (2006) Tree recruitment and growth on 20-year-old, unreclaimed surface mined lands in West Virginia, International Journal of Mining, Reclamation and Environment, Vol. 20(2), pp. 142-154.

Soane, B.D. (1990) The role of organic matter in soil compactibility: A review of some practical aspects, Soil and Tillage Research, Vol. 16(1-2), pp. 179-201.

Strong, W.L. (2000) Vegetation development on reclaimed lands in the Coal Valley Mine of western Alberta, Canada, Canadian Journal of Botany, Vol. 78, pp. 110-118.

Timoney, K.P., La Roi, G.H., Zoltai, S.C. and Robinson, A.L. (1993) Vegetation communities and plant distributions and their relationships with parent materials in the forest-tundra of Northwestern Canada, Ecogeography, Vol. 16(2), pp. 174-188.

Tisdall, J.M. and Hodgson, A.S. (1990) Ridge tillage in Australia: a review. Soil and Tillage Research, Vol. 18(2-3), pp. 127-144.

Tordoff, G.M., Baker, A.J.M. and Willis, A.J. (2000) Current approaches to the revegetation and reclamation of metalliferous mine wastes, Chemosphere, Vol. 41, pp. 219-228.

Van den Driessche, R. (1999) First-year growth response of four Populus trichocarpa x Populus deltoïdes clones to fertilizer placement and level, Canadian Journal of Forest Research, Vol. 29, pp. 554-562.

Washburn, B.E., Hughes, H.G. and Storm, G.L. (1994) Influence of seeding level upon plant community dynamics on reclaimed mined lands in Pennsylvania, in Proceedings of the International Land Reclamation and Mine Drainage Conference and the 3rd International Conference on the Abatement of Acidic Drainage, Pittsburgh, PA, April 24-29, pp. 285-294.

Wisniewski, L. and Dickinson, N.M. (2003) Toxicity of copper to Quercus robur (English Oak) seedlings from a copper-rich soil, Environmental and Experimental Botany, Vol. 50, pp. 99-107. 